УДК 37.091.31:004.9:316.77](091)

Пінчук Ольга Павлівна

кандидат педагогічних наук, старший науковий співробітник, завідувач відділу технологій відкритого навчального середовища

Інститут інформаційних технологій і засобів навчання НАПН України, м. Київ, Україна

opinchuk100@gmail.com

\title{
ІСТОРИКО-АНАЛІТИЧНИЙ ОГЛЯД РОЗВИТКУ СОЦІАЛНИХ МЕРЕЖНИХ ТЕХНОЛОГІЙ І ПЕРСПЕКТИВ ЇХ ВИКОРИСТАННЯ У НАВЧАННІ
}

\begin{abstract}
Анотація. У статті подано короткий історичний опис виникнення і дослідження соціальних мереж, результати сучасних досліджень у філософських і психологічних науках, соціальних комунікаціях i економіці. Проаналізовано сучасний стан педагогічних досліджень електронних соціальних мереж і формування практичного досвіду їх використання. Результати досліджень соціальних мереж вивчено й описано з точки зору їх формування в умовах розширення комунікаційного простору глобалізованого соціуму і трансформації старих, а також появи нових практик взаємодії соціальних суб'єктів у різних сферах життєдіяльності суспільства, в освіті зокрема. У використанні електронних соціальних мереж автор вбачає потенціал розв'язання проблем синхронізації різних освітніх форматів для побудови цілісної траєкторії індивідуального навчання.
\end{abstract}

Ключові слова: електронні соціальні мережі; інформаційно-освітнє середовище; інформаційно-комунікаційні технології; навчання.

\section{1. ВСТУП}

Соціальне замовлення суспільства й вимоги сучасного ринку праці активно впливають на формування стратегії модернізації освіти України [33; 28]. Оволодіння i використання різних сервісів Інтернету вже нині $\epsilon$ невід'ємним компонентом інформаційної культури людини. Організація ефективної інформаційної діяльності фахівця практично всіх сфер професійної діяльності найчастіше не обходиться без використання соціальних мережних сервісів (соціальні пошукові системи, народні класифікатори, Вікі-проекти, онлайн офіси, карти знань, соціальні медіа-сховища, блоги, ресурси соціальних мереж).

Дослідження [19] показують, що в середньому доросла людина в розвиненому цифровому світі проводить за переглядом різних цифрових медіа 5,7 години на день цей показник подвоївся за останні 7 років. Активність сучасних інтернет-користувачів зосереджується навколо візуального контенту, обміну ним, класифікації і створення власного у форматі репост, фан-творчості, мемів, а також рецензій і рейтингів. Тенденції, що виявили себе на більш розвинених у цифровому відношенні територіях, зокрема в США, проявляються в Україні із запізненням на кілька років, тому в нас $є$ рік-два, щоб підготуватися до нових реалій.

Постановка проблеми. У доповіді «Reimagining teaching» [29], присвяченій викладанню в «змішаному» класі, де використання відкритих освітніх ресурсів (OpenEducationalResources, OER) фактично ототожнюється 3 очними заняттями, описані три можливих професійних траєкторії, що представляють альтернативу моделі «Лектор». Це, у першу чергу, «Дослідник і розробник» (Researcher\&Developer), який намагається уникати використання традиційних методів педагогіки, випробовуючи все нові способи подання навчального матеріалу. Він швидко знаходить слабкі сторони діючих методик і змінює інструменти. «Інтегратор» (Integrator) не придумує нових рішень, але вибирає існуючі методики згідно спостережень за успіхами і поведінкою 
своїх учнів. Це - експерт 3 перевірки на якість нових ресурсів та педагогічних інструментів.

У нашому дослідженні на особливу увагу заслуговує наступний тип трансформації педагогічної професії, а саме «Інструктор/Куратор» (Guide). Він вибирає способи подання матеріалу, виходячи з побажань самих учнів, допомагає підібрати навчальні ресурси для самостійного їх вивчення. За останні два десятиліття педагогічна практика збагатилася такими інноваціями, як використання засобів мультимедійних технологій, інтернет зв'язку, тренажерів-симуляторів, віртуалізації тощо. Деякими дослідниками (Петухова Л. С, Співаковський В. О.) було запроваджено поняття «трисуб'єктна дидактика», у межах якої сучасними вченими-педагогами активно розроблясться організація навчального процесу в умовах тріади «учитель - учень активне інформаційно-комунікаційне педагогічне середовище навчання» [32]. Фундаментальний принцип індивідуалізації навчання знаходить своє втілення в програмному забезпеченні навчального призначення i реалізується в особистих налаштуваннях (дизайн, шрифт, режим), особистому профілі (кабінет, сторінки, портфоліо, папки), можливості варіювати темп навчання, обсяг і складність матеріалу, додавати власний контент та багато іншого. В освітній практиці все частіше трапляються ситуації, коли учні старших класів, студенти одночасно з відвідуванням очних занять працюють над власними проектами, є слухачами онлайн курсів. Наразі всі ці різні освітні формати залишаються несинхронізованими замість того, щоб складати цілісну й осмислену траєкторію навчання. Ця ситуація породжує запит на нові педагогічні професії, наприклад, «розробник індивідуальних освітніх траєкторій». Які засоби комунікації обере цей фахівець? Наш аналіз останніх досліджень у цій галузі показав, що в умовах розширення комунікаційного простору глобалізованого соціуму і трансформації старих, а також появи нових практик взаємодії соціальних суб'єктів у різних сферах життєдіяльності суспільства, в освіті, зокрема, першочергового значення набувають дослідження електронних соціальних мереж. Розширення комунікаційного простору, у свою чергу, значною мірою обумовлено технологізацією соціальних практик і процесами інформатизації, медіятизації і дигіталізації форм взаємодії соціальних суб'єктів.

За останніми даними 3 початку 2000-х рр. ми переживаємо бум каналів постачання контенту, «контрольованого» користувачем, - від розміщення відео файлів у соціальних мережах до сервісів потокового відео й ігрових консолей. Найбільш активною і мобільною групою інтернет-користувачів залишаються молоді люди у віці 12-24 роки. Це, у першу чергу, старшокласники і студенти. До молодих людей суспільство висуває нові вимоги: уміти співпрацювати, ефективно працювати як індивідуально, так і в команді, знаходити спільні рішення, розв'язувати конфлікти на основі узгодженості позицій і врахування інтересів, формулювати, аргументувати та відстоювати власну думку.

На думку вчених (Л. І. Божович, Л. С. Виготський, В. В. Давидов, А. Н. Леонтьєв, А. В. Петровський, Д. І. Фельдштейн, Д. Б. Ельконін) сенситивним періодом для освоєння широких соціальних зв'язків і відносин, самовизначення дитини в суспільстві $\epsilon$ підлітковий вік. Оскільки провідним видом діяльності підлітка виступає спілкування з однолітками, складається нова соціальна ситуація розвитку (Л. С. Виготський), на основі якої будуються між особистісні взаємини. Соціальна ситуація розвитку в підлітковому віці характеризується, по-перше, зміною внутрішньої позиції по відношенню до школи й навчання. Підліток, не ігноруючи навчання, надає особливого значення спілкуванню. У спілкуванні з однолітками він розширює межі своїх знань, розвивається в розумовому відношенні, ділячись своїми знаннями і демонструючи освоєні способи розумової діяльності. Спілкуючись з однолітками, підліток осягає різні 
форми взаємодій людини з людиною, учиться оцінювати можливі результати свого і чужого вчинку, висловлювання, емоційного прояву. Підлітки жадають спілкування, i це, зазвичай, відбувається після занять у школі. Дорослий друг, дорослий кумир, на думку психологів, є досить рідкісним явищем в індивідуальному житті підлітка. Проте дорослий, якого шанують і до якого прислуховуються, - досить розповсюджене явище у підлітковій групі. Добре, коли ця значуща людина - учитель, керівник спортивної секції, наукового об’єднання тощо.

Підлітки, особливо у великих містах, володіють реальними можливостями доступу до якісного Інтернету, використовують мобільні засоби зв'язку, а, отже, застосовують і нові форми взаємодії, що, безумовно, має знайти відображення у навчанні. Тому нові можливості у здійсненні педагогічної взаємодії мають бути враховані під час трансформації освітніх систем.

Аналіз останніх досліджень і публікацій. Комп'ютерні мережі - основні універсальні засоби соціальної комунікації, вважає Мнацаканян О. Л. [21, с.9]. На нашу думку, використання електронних соціальних мереж в освіті може мати синергічний ефект, пов'язаний, зокрема, з тим, що комбіноване використання кількох взаємоузгоджених педагогічних стратегій виявляється кориснішим, аніж ізольоване впровадження якоїсь однієї. Сумуючий ефект за взаємодії декількох факторів (методики змішаного навчання, використання засобів мультимедійних технологій у традиційному навчанні, використання LMS завдяки використанню електронної соціальної мережі (ЕСM) може суттєво переважати ефект кожного окремого компонента у вигляді простої їх суми.

Так, дослідники розвитку громадянського суспільства [23] вважають, що процеси конвергенції мережних технологій, мобільних засобів зв'язку, мобільних комп’ютерів і систем геопозиціонування сприяють більш повній залученості мільйонів людей у мережний простір, що створює умови для використання їх творчого потенціалу для розв'язання наукових, суспільно значущих проблем.

Галіч Т. О доводить, що суспільство, ключову комунікативну роль у якому починають відігравати мережі, вільно формує об'єднання людей і групи за інтересами. На відміну від традиційних соціальних структур «мережі здатні сприймати і самостійно створювати нові комунікативні конфігурації, недоступні для традиційних інститутів». Основою такого суспільства $є$ мережна комунікація, однією з форм вираження якої $є$ помітне зростання кількості соціальних Інтернет-мереж. Вони виступають інструментом, за допомогою якого велика кількість користувачів глобальної мережі отримують додаткові можливості у спілкуванні і взаємодії [9, с. 145].

Сучасні комунікаційні технології дозволяють створювати соціальні спільноти 3 практично будь-якими заданими характеристиками - освітніми, професійними, віковими [2].

Уже нині згідно опитування, проведеного консалтинговою фірмою Hallvarsson\&Hallvarsson (Швеція) серед 700 компаній з 21 європейської країни, 81 \% опитаних розвиває корпоративні соціальні мережі, вважаючи їх чудовим інструментом для створення лояльності серед співробітників, маркетингових комунікацій 3 користувачами, формування іміджу, вивчення динаміки попиту, а також розповсюдження інформації про себе.

Використання соціальних мереж з метою накопичення й отримання знань стає економічно рентабельним. Наразі мережі впроваджуються на критично важливих ділянках процесу обробки знань - генерації ідей, опрацювання великих обсягів інформації, інноваційному менеджменті. Інтелектуальний контент, що міститься в соціальних наукових мережах, є новим типом інформаційних ресурсів і становить частину національного інтелектуального капіталу [23]. 
Вважаємо, що на наш час не існує системних теоретичних та методологічних розробок щодо ЕСМ в освіті. Переважна більшість тематичних видань або дають занадто загальну описову картину, або аналізують вузькопрофільні питання. Зазвичай, публікації присвячуються практиці SMM(SocialMediaMarketing), аналізуючи переважно методи збирання, дослідження та поширення інформації щодо об'єкту промоції. На думку деяких дослідників, це $\epsilon$ ознакою того, що «... цей напрям людської діяльності ще й досі перебуває в межах процесів формування первинної інструментальної бази, яка згодом потребуватиме методологічного опрацювання» [14, с. 42].

Треба зауважити, що останніми роками в діяльності блогерів-педагогів, учасників загальнодоступних тематичних груп на Фейсбуці (наприклад: ІКТ-навчання педагогів України, Навчаємося 3 Google, Образовательные технологи, ПК у фізичному експерименті) і професійних кіл на Google+ спостерігається формування практичного досвіду, активізація спроб використання можливостей соціальних мережних сервісів у педагогічній практиці. Але цей процес не супроводжується дидактичним і психологопедагогічним обгрунтуванням.

Отже, проблема використання технологій електронних соціальних мереж у навчанні старшокласників набуває виключної актуальності. Аналіз джерельної бази показав, що використання ЕСМ в навчанні не знайшло достатнього обгрунтування.

Мета статті. Проаналізувати концептуальні положення соціальної філософії, соціології та психології щодо формування соціальних мереж, стан дослідження проблеми у наукових педагогічних публікаціях, практичний досвід використання електронних соціальних мереж (ЕCM) у навчальному процесі, визначити організаційні форми навчання, у яких використання ЕСМ є найбільш ефективним.

\section{2. ТЕОРЕТИЧНІ ОСНОВИ ДОСЛІДЖЕННЯ}

Теоретичну основу нашого дослідження склали концептуальні положення вітчизняної і закордонної соціальної філософії, соціології та психології, вироблені під час розв'язання проблем дослідження розвитку і функціонування соціальних мереж у сучасному суспільстві.

Основу запропонованого в роботі підходу склали:

- теорії соціальних мереж (А. Бейвлас, С. Берковіц, П. Марсдеа, Дж. Морено, Б. Уеллман, Л. Фріман та ін.);

- вітчизняні й закордонні концепції міжособистісної взаємодії (Б. Г. Ананьєв, А. А. Леонтьєв, В. М. Мясищев, Б. Ф. Ломов, З. Фрейд,А. Адлер, Г. Г. Келлі та ін.);

- концепції комунікаційних i мережних трансформацій, що відбуваються в умовах модернізації сучасного суспільства (У. Бек, Р. Берт, М. Гранновертер, М. Кастель, Дж. Коулмен, Г. Лорі, Д. Старк і Дж. Уррі та ін.);

- дослідження, що присвячені проблемам інформатизації освіти (В. Ю. Биков, Р. С. Гуревич, М. І. Жалдак, А. М. Гуржій та ін.);

- науково-педагогічні засади формування і застосування інформаційних освітніх середовищ (В. Ю. Биков, Ю. О. Жук, В. В. Олійник, С. С. Полат та ін.).

\section{3. МЕТОДИКА ДОСЛІДЖЕННЯ}

У дослідженні використано низку теоретичних методів: аналіз стану дослідження проблеми у наукових публікаціях; вивчення практичного досвіду використання електронних соціальних мереж (ECM) у навчальному процесі; ретроспективний аналіз 
виникнення i розвитку понять «соціальна мережа» i «ЕСМ» у їх історичній послідовності; методи порівняльного аналізу, конкретизації та проектування з метою визначення організаційних форм навчання, у яких використання ЕСМ $\epsilon$ найефективнішим.

Дослідження виконане в межах науково-дослідної роботи «Формування інформаційно-освітнього середовища навчання старшокласників на основі технологій електронних соціальних мереж» (№ ДР 0115U002232).

\section{4. РЕЗУЛЬТАТИ ДОСЛІДЖЕННЯ}

\section{1. Короткий історичний опис виникнення і дослідження соціальних мереж}

Перше звернення до соціальних структур як поняття соціальної філософії другої половини XIX ст. можна знайти в роботах Давида Емілья Дюркгейма (фр.), Георга Зіммеля (нім.) і ГербертаСпенсера (англ.). Дослідниками були сформульовані базові аспекти аналізу мережного суспільства.

Системна наукова основа механізмів вивчення соціальних мереж віднайшла свій початок у дослідженнях провідних соціологів 30-х років XX ст. Ключовими роботами в дослідженні природи соціальних мережі донині вважають праці А. Бейвласа i Дж. Морено. У них автори на основі експериментальних даних вперше змогли побудувати просторові форми соціальних об'єктів. Теоретико-методологічні основи аналізу соціальних мереж, закладені дослідниками, стали базою для цілого напряму соціальної філософії, предметом вивчення якої є формування «мережі стосунків».

Дж. Морено запровадив поняття «соціограми», розуміючи під ним схематичне зображення міжособистісних відносин у соціальній групі [22]. Сам термін «соціальна мережа» у 1954 р. запропонував Джеймс Барнс (амер.) [4]. Вважається, що значення, яке вкладав автор у це поняття, максимально відповідає сучасному визначенню соціальних мереж.

Соціальні мережі вперше були досліджені в кінці 1940-х років. Ще до створення інтернету соціолог Марк Грановеттер (амер.) і математик Лінтон Фріман (амер.) опублікували основоположні матеріали за цією тематикою [18; 37]. М. Грановеттер визначив, що всередині соціальних мереж слабкі зв'язки (сусіди, знайомі, знайомі знайомих, формальні контакти на роботі) мають більше значення, ніж сильні (родичі, друзі). Пояснюється це тим, що інформація швидше і ширше розповсюджується саме через слабкі зв'язки. Більш сильну теоретичну аргументацію на користь тези про силу слабких зв'язків запропонував Рональд Берт (амер.) у своїй теорії «структурних дір» [6].

У 60-ті роки XX ст. математики П. Едьош і А. Реньї вперше застосували математичні методи задля ілюстрування принципів розбудови соціальних мереж, зокрема за допомогою теорії випадкових графів. Також було сформовано концепцію «малих світів», що передбачає наявність коротких шляхів між двома будь-якими вершинами.

Наприкінці XX - початку XXI ст. з'явилися віртуальні соціальні утворення. У 1995 р., під авторством Ренді Конрадса, з'явилася Classmates.com - перший інтернетсайт, який пропонував можливості роботи із соціальними мережами. Слідом за ним у 1997 році з'явився SixDegrees.com. Починаючи з 2001 року, з'являються сайти, у яких використовувалася технологія під назвою «Коло друзів». Ця форма соціальних мереж, яка й нині використовується у віртуальних спільнотах, набула широкої популярності в 2002 році й розквітла 3 появою сайту Friendster. Наразі, експерти нараховують більше ніж 200 сайтів 3 можливостями організації соціальних мереж. У соціальних мережах 
користувач знаходиться в центрі системи і може належати до декількох груп водночас. Світ побачили Friendster (2002), Linkedln (2003), MySpace (2003), Tribe (2003), Hi5 (2003),Orkut, Bebo, Yahoo 360 (2004). У 2004 році Марк Цукерберг створив Facebook, що є нині беззаперечним лідером у світі соціальних мереж. На теренах СНД першими були: Мой круг (2005), Одноклассники.ru (2006) та ВКонтакте.ru (2006). Українські соціальні мережі: Connect.ua - український сайт знайомств, створений у грудні 2007 року, як «соціальна мережа знайомств», але пізніше переорієнтований виключно на знайомства; мережа «Українські науковці у світі» - наукова спільнота, покликана консолідувати український інтелект у світі. (2008, UkrainianScientistsWorldwide).

3 початком функціонування віртуальних об'єднань соціальна комунікація набула нових якостей: оперативності, глобальності, системності. Утім, зазнала змін лише форма, зміст - базові комунікаційні закони - залишився незмінний [14, с.41].

На нашу думку, зважаючи на порівняно довгу історію існування терміна «соціальні мережі», їх вивчення має порівняно коротку історію. Вивченням мережних об'єктів довгий час займалися представники різних наукових напрямків: філософії, соціології, антропології, психології, теорії комунікацій і політичних наук. У результаті такого підходу була сформована аксіоматична модель соціальної мережі (Б. Уеллман, Б. Еріксон, С. Берковіц, П. Марсден, Л. Фріман). Засновниками кібернетики (Н. Вінер, Р. Хартлі, Дж. Фон Нейман і К. Шеннон) було зроблено акцент на інформаційній складовій соціальних об'єктів. Отже, будь-яка соціальна структура не є цілісним об’єктом. В їі основі лежать два об'єкти: комунікація (граф) і актор (вершина). Суб’єктом у соціальній мережі можуть виступати як окремі індивіди, так і усуспільнені групи. Комунікація може виступати як структурна одиниця соціальної мережі за наявності певних умов: цілісності, визначеності напряму, повторюваності та тривалості існування. Якщо комунікація має разовий характер, іiі не можна розглядати як структурну одиницю соціальної мережі.

\section{2. Визначення електронних соціальних мереж}

У вивченні понятійного апарату дослідження нами було використано герменевтичний підхід. Відразу зазначимо, що в сучасних дослідженнях використовують терміни «електронна соціальна мережа» i «соціальна інтернетмережа», які $\epsilon$ семантично рівноправні. Використання терміну «соціальна мережа» здається авторам більш зручним і найпоширенішим, проте воно є більш широким i визначається контекстно.

У більшості робіт не наводиться чіткої дефініції соціальної мережі. Якщо визначення дається, то воно, як правило, не може бути співставленим з визначенням цього ж поняття в інших авторів. Поняття «соціальна мережа» має кілька значень у понятійно-категоріальному апараті соціології. Так, наприклад, у Матрьохіно \Н. В. [20, с. 3] «соціальна мережа» визначається як суб'єктивна реальність міжособистісних взаємодій людини зі значимими для неї людьми. Соціальна мережа супроводжує людину протягом усього життєвого циклу, виступає елементом загального соціального середовища. Через неї людина включається у суспільство, набуває соціальний досвід, освоює соціальні норми, правила, формує свої цінності іi установки. У соціальній мережі відбувається обмін ресурсами як матеріальними, так і нематеріальними.

Виходячи 3 того, що для існування терміну необхідне існування відповідної предметної галузі, окреслюємо звуження розглядуваних міжособистісних взаємодій у мережі шляхом використання слова «електронні», що означає таку характеристику мережі, як доступність для обробки даних електронними (цифровими) пристроями.

3 технологічної точки зору електронна соціальна мережа - це інтерактивний, 3 
великою кількістю користувачів веб-сайт, контент якого наповнюється самими учасниками. Сайт $\epsilon$ автоматизованим соціальним середовищем, яке дозволяє спілкуватися групі користувачів, об'єднаних загальним інтересом. Теоретично як соціальну мережу можна розглядати будь-яку онлайнову спільноту. Наприклад, соціальна мережа утворюється читачами тематичного співтовариства, створеного на будь-якому сервісі блогів [9, с. 150].

Деякі автори визначають ЕСМ як «технологічні комплекси організації і управління обмінами електронною інформацією між суб' єктами соціальних відносин, призначені для забезпечення горизонтального спілкування зацікавлених у ньому абонентів, об'єднаних спільними інтересами, інформаційними потребами і навичками спілкування» [23].

Основна риса справжньої ЕСМ (прагматичний підхід, 2007): користувачі можуть конструювати публічний або напівпублічний профіль, зазначивши список тих, 3 ким хочуть налагодити зв'язок і переглядати й передавати свій список контактів і списки інших користувачів системи [30]. Розвиток технологій керування контактами привів до розробки технологій, за яких користувачі могли б об'єднуватись у «племена» довкола спільного зацікавлення (патент компанії Tribe) - сервіс створення двостороннього комунікаційного ланцюга (прийняти запрошення й підтвердити дружбу).

Сучасні ЕСМ стають необхідним робочим інструментом для людської діяльності, будь то бізнес, навчання чи творчість. Зокрема, ЕСМ перетворюються на інструмент інформаційного впливу й маніпулювання масовою свідомістю [31].

Підсумовуючи вище зазначене, підкреслимо: основним об'єктом у ЕСМ $\epsilon$ людина, а не інформація!

У різних ЕСМ - різний інтерфейс і цільове призначення, своя аудиторія, механізми роботи. У кожної мережі є свої правила, яких користувач в обов'язковому порядку повинен дотримуватися. Універсальної класифікації видів ЕСМ у світовій спільноті не існує. Найчастіше виділяють «професійні» або «мережа професійних контактів» (LinkedIn, e-LearningPRO), «традиційні» або «універсальні» (Facebook, MySpace, Вконтакте, Одноклассники), «для авторських записів» (Twitter), «за інтересами» або «тематичні», «академічні» або «дослідницькі» (Academia.edu, ConnoteaCollaborativeResearch, Українські науковці у світі) та «освітні» (TheStudentRoom, TheMathForum, ePALSSchoolBlog,Yammer). Освітні соціальні мережі об'єднують студентів/учнів і орієнтовані на взаємодію з метою надання допомоги в реалізації академічних проектів, проведення наукових досліджень, або взаємодії 3 викладачами/учителями.

\section{3. Результати сучасних досліджень соціальних мереж у філософських $\mathbf{i}$ психологічних науках, соціальних комунікаціях й економіці}

Яценком А. Л. [38, с. 8-9] розглянуто еволюцію феномена соціальної мережі як самоорганізованої гнучкої системи соціальних взаємин. Доведено, що функціональні, морфологічні і змістові особливості соціальної мережі знаходяться у безпосередній залежності від тих типів комунікаційних зв'язків, які $\epsilon$ для неї домінуючими. Особливість дії комунікаційного механізму з формування мережі полягає в тому, що мережа створюється і підтримується не тільки і не стільки за рахунок безпосереднього приєднання до неї індивідів і їх груп, скільки за рахунок формування у цих індивідів або їх груп інтерпретаційних скриптів, необхідних для комунікаційного обміну. Іншими словами: визначальними є стандартизовані акти взаємодії з фіксованими комунікативними складовими, за допомогою яких індивід, перебуваючи у внутрішньо комунікаційному просторі, осягає навколишній світ. 
Сучасні теоретики інформаційного суспільства звертають увагу на те, що самоорганізація мережних структур інспірується не так обсягом циркулюючої між соціальними суб'єктами інформації (зростаючій в умовах розвитку кіберпростору), як якістю, характером цієї інформації, способом її використання. Підтримуємо думку про те, що найціннішим у теоріях постіндустріалізму $є$ також принципова зміна вектора пізнавального інтересу від технології до соціального суб' єкта, що є провідником у світ інформації і її продуцентом.

На думку Яценко А. Л. [38, с. 18-19] позитивні чи негативні оцінки розвитку мережної форми взаємодії часто є продовженням один одного і відображають, з одного боку, позитивне сприйняття зростаючого ступеня свободи індивідів від жорсткої соціальної детермінації і захоплення від нових комунікаційних можливостей, а з іншого боку, відтворюють зростаючий песимізм, збудований на побоюваннях залежності від техніки й інформаційних технологій, а також втрати свободи внаслідок зростання звикання і підпорядкованості того ступеня комфорту, який уже досягнуто і продовжує зростати. Побоювання також викликає все зростаюча дезорганізація цінностей, подолати яку можливо тільки за допомогою звернення до базових загальнолюдських цінностей.

Автором було доведено, що різні за своєю формою соціальні мережі є основними об'єктами, що функиіонують поверх $i$ поза глобальною мережею Інтернет. Вони продовжують виступати базисним механізмом конструювання комунікативного простору сучасного суспільства. Проте використання сучасних засобів комунікації принципово знижує втрати і спотворення під час передавання відомостей. Спрощується і прискорюється процес спонтанного створення територіально розподілених соціальних мереж, що характеризуються повною децентралізацією.

Курбан О. В. [14, с. 42], класифікуючи з позиції сфери зв'язків із громадськістю «усі наявні на теперішній момент соціальні мережі» визначив два їх види: 1) віртуальні (передбачає кібернетичний варіант комунікації у форматі інтернет (міжособиста, міжгрупова, масова) й інтранет (міжособиста, внутрішньогрупова)); 2) реальні (профільні організації; професійні утворення; дозвільні об’єднання).

Матрьохіною Н. В.[20, с. 3-4] вивчено якісні і кількісні характеристики соціальної мережі як суб'єктивного образу міжособистісних взаємодій. Ії ївікову динаміку. Соціальна мережа визначається як суб'єктивна реальність міжособистісних взаємодій людини зі значимими для неї людьми. До структурних і функціональних характеристик соціальної мережі людини авторка відносить: обсяг контактів, об'єкти взаємодії, зміст міжособистісних взаємодій, взаємність, близькість або дистанційованість, емоційна забарвленість, інтенсивність міжособистісних взаємодій, згуртованість мережі.

Лещенко О. М. [16, с. 6-7] досліджено соціальні мережі як феномен соціальної реальності, що відображає специфіку мережної комунікації в інформаційному суспільстві. Автор характеризує соціальні мережі періодичністю, інформаційноаналітичною і фінансовою доступністю, а також глобальністю, демократичністю i наявністю зворотного зв'язку, що розкриває їх конструктивний потенціал у сучасному комунікативному просторі. Основними характеристиками вважає мультифункціональність і соціабельність, які підвищують ефективність мережної комунікації за рахунок формування інформаційної компетентності й інформаційної культури особистості.

Попри це, що мультифункціональність і соціабельність соціальних мереж сприяють мобільності соціального капіталу, усередині самих соціальних мереж народжуються ціннісні імперативи. Так, важливе місце в процесі функціонування соціальної мережі відіграє «мережний етикет», який гарантує, що кордони віртуального 
співтовариства знаходяться під контролем. В управлінні соціальними акторами виникає проблема саморегуляції соціальної мережі, що у своїй основі містить нове розуміння свободи, відповідальності, ідентичності [16, с. 22].

В умовах глобалізації й інтенсивного розвитку інформаційних технологій ЕСМ симбіоз соціальної і технічної реальності, що утворює різноманітні комунікативні конфігурації (просторово-часові, суб' єкт-суб' єктні, суб' єкт-об' єктні), які компенсують високу інформаційну щільність сучасного суспільства і здійснюють всі види соціальної комунікації (масової, міжособистісної, групової) на всіх технологічних рівнях: вербальному, письмовому, аудіовізуальному.

Аксіологічний статус соціальних мереж полягає в тому, що вони виступають механізмом конструювання сучасного комунікативного простору сучасного суспільства за рахунок накопичення і реалізації соціомережного капіталу і дифузії інновацій, які охоплюють освітню, науково-інноваційну, політичну та економічну сфери сучасного суспільства [16, с.8]. Аксіологічний статус ЕСМ у сучасному інформаційному суспільстві проявляється в тому аспекті, що вона $є$ засобом накопичення і реалізації особистого і соџіального капіталу [16, с. 21].

Щодо моделювання спеціалізованих соціальних мереж й оцінювання ефективності взаємодій у них між акторами мережі цікавою і перспективною для впровадження в галузі освіти, на нашу думку, є робота Акимова С. О. [1]. У розробленій автором моделі корпоративна соціальна мережа представляється у вигляді сукупності множин: множина співробітників компанії, множина інформаційних i комунікаційних інструментів (інструментів мережі), множина активностей (множина всіх синхронних i асинхронних комунікацій i самостійних дій співробітників 3 використанням інструментів мережі), множина компетенцій компанії.

Автором розроблено методику визначення ступеня активності користувача корпоративної соціальної мережі у ролі комунікатора, в основу якої покладено принцип розрахунку рейтингу комунікаторів. Методика дозволяє виявляти співробітників, які беруть активну участь у процесі обміну знаннями. Методика дозволяє визначати ефективність соиіальної мережі в контексті управління знаннями (УЗ) і порівнювати ефективності використання соціальної мережі в контексті УЗ двома різними колективами. Акімовим С. О. обгрунтовано можливість побудови системи УЗ на базі корпоративної соціальної мережі. Розроблено імовірнісну модель розвитку компетенцій співробітників у результаті їх активності в корпоративній соціальній мережі, яка дозволяє оцінювати ймовірності набуття співробітниками компетенцій на основі показників їх активності в соціальній мережі [1, с. 7-8].

Аналіз ЕСМ відбувається так. Спільна активність пари користувачів мережі $(\mathrm{i}, \mathrm{j})$ в корпоративній соціальній мережі може відбуватися за допомогою будь-якого 3 8 основних інструментів мережі: миттєві повідомлення, форуми, блоги, wiki-бібліотеки, сховища документів, соціальні закладки, сховища навчально-методичних матеріалів i електронних курсів, відеоконференції. Для кожної пари користувачів, які обмінюються інформацією, по кожному з 8 способів спілкування розраховується набір кількісних показників інтенсивності спілкування. Оскільки співробітники, використовуючи інструменти мережі, спілкуються в корпоративній соціальній мережі переважно у вигляді тексту (в інших випадках регламентується обов'язкове протоколювання спілкування) додатково можуть бути використані методи тематичного аналізу тексту [1, c. $10-11]$.

У роботі як кількісна характеристика спілкування користувачів використовується поняття «отримана одиниця інформації»- унітарна неподільна сутність, що є логічно завершеною думкою, переданою у вигляді даних (тексту, відео тощо) від одного користувача (передає одиницю інформації, наприклад, учитель) до іншого (одержувач 
одиниці інформації - учень). У даній роботі кількість «отриманих одиниць інформації» трактується як кількість простих речень, отриманих співробітником у результаті активності в мережі. Отримання одним або кількома співробітниками набору одиниць інформації є результатом активності співробітників у мережі. Акімов С. О. визначає два типи одиниць інформації (тематична і нетематична), що визначають три типи активностей співробітників у соціальній мережі (учитель, учень, комунікатор).

Таким чином, для кожної пари $(i ; j)$ користувачів мережі $\mathrm{i}$ компетенції $k$ розраховуються показники тематичного спілкування. Для цього використовують всі 8 інструментів. Якщо використовують тільки сховища документів, навчальнометодичних матеріалів та електронних курсів, то формують показник самостійної активності по компетенції.

Отже, виходячи 3 аналізу згаданих вище досліджень, можна зробити певні висновки.

1. Соціальна мережа як елемент соціального середовища пов'язує дві системи: людину і суспільство.

2. Соціальні мережі є основними об’ єктами, що функціонують поверх і поза глобальної мережі Інтернет.

3. Структурними i функціональними характеристиками соціальної мережі людини можуть слугувати: обсяг контактів, об'єкти взаємодії (люди (вік, стать, освіта...), групи/круги, організації/установи), зміст взаємодій, емоційна забарвленість, інтенсивність міжособистісних взаємодій.

4. 3 точки зору соціальної психології «соціальна мережа» - егоцентрична мережа, у якій усі їі члени «обертаються» навколо однієї людини. J. C. Mitchell (1969) визначає соціальну мережа як специфічний набір зв'язків людини з певними людьми, що впливають на соціальну поведінку даної людини. Мова йде про соціальну підтримку людини, ті дії членів мережі, які дають людині впевненість у тому, що іiі люблять, цінують, що вона значима в їхньому житті. I саме це $є$ істотною відмінністю від ЕСМ у сучасному розумінні цього терміну.

5. Із соціологічної точки зору, ЕСМ $є$ своєрідним соціальним капіталом людини, у ЕСМ відбувається обмін нематеріальними ресурсами.

6. Аналіз транзакцій, що відбуваються у мережі між іiі членами, може бути основою для формування уявлення про зміст та цілепокладання міжособистісної взаємодії.

7. Враження, що ЕСМ людина використовує у першу чергу для побудови відносин, близького спілкування, комунікації, - хибне. Обсяг міжособистісних взаємодій людини є скінченним і у різному віці змінюється у межах від4 до 14 осіб [20, c. 6]. Отже, Людина на може підтримувати коло спілкування у сотні осіб, які у нього в «друзях». Проте людина може шукати соиіальну підтримку (підтримувальні дії): інформаційну підтримку (розуміється як надання необхідної інформації людині й задоволення iї комунікаційної потреби); пораду (порада $є$ прямим керівництвом, конкретною вказівкою в директивній формі); емоційну підтримку; інструментальну підтримку (отримання конкретної дієвої допомоги, розглядається як надання великих і дрібних послуг, допомога конкретними практичними діями), а також може шукати аудиторію для самовираження, ресурси для власного розвитку.

8. У старшому шкільному віці відбувається диференціація контактів людини. Починають формуватися «Круги спілкування»: кількість близьких відносин зменшується, збільшується кількість дискантних. Отже, цілком очевидно вважати перспективним використання ЕСМ у процесі формування інформаційно-освітнього середовища навчання старшокласників. 
9. ЕСМ мають ціннісний потенціал за рахунок накопичення $\mathrm{i}$ реалізації соціомережного капіталу і дифузії інновацій, які охоплюють освітню й науковоінноваційну сфери сучасного суспільства.

10. Спеціалізовану/тематичну/профільну електронну соціальну мережу можна представити у вигляді сукупності множин: множина людей-учасників, множина інструментів мережі, множина активностей, множина компетенцій. Під час аналізу ЕСМ можна доцільно використовувати показники: частота відвідування, час, що витрачено на відвідування мережі, кількість акторів, вік основної аудиторії, показник тематичного спілкування, показник самостійної активності з компетенції, а також залучати методи тематичного аналізу тексту.

\section{4. Сучасний стан педагогічних досліджень електронних соціальних мереж}

Починаючи 3 2007-2008 років, в університетах США стали активно експериментувати з упровадженням сервісів соціальних мереж у навчальний процес. Уже через 2-3 роки переважна кількість навчальних закладів мала свої офіційні сторінки в Facebook, Twitter, YouTube, вважаючи цей досвід вдалим маркетинговим кроком. Почали з'являтися онлайн спільноти викладачів і спеціалістів у галузі еLearning. Виявилося, що ЕСМ сприяють розвитку електронного навчання й освіти в цілому, оскільки пропонують нові технічні й методичні рішення. Переважна більшість закордонних дослідників вважає, що у справі розвитку організації і методичної підтримки електронного навчання треба орієнтуватися не на LMS, що є негнучкими інструментами, а на популярні соціальні мережі [36]. Оскільки навіть системи 3 відкритим кодом, такі як Moodle, не дозволяють (без істотного налаштування) використовувати компоненти інших розробників. Водночас, загальнодоступні соціальні інструменти і засоби взаємодії і співпраці мають безперечні переваги у справі побудови власного навчального простору. Так, завдячуючи соціальним сервісам, у системі дистанційного навчання відбувається еволюція від LMS до PLE(PersonalLearningEnvironments).

3 точки зору привабливості для навчального середовища соціальні мережі вивчали Архіпова Т. Л. [3], Вилегжаніна І. В. [8], Воронкін О. С. [7, с. 656-654, с. 662663], Гуревич Р. С. [10], Дюлічева Ю .Ю. [11],Івашньова С. В. [12], Крибель С. С. [13], Малишева Н. О. [17], Мнацаканян О. Л. [21], Павличенко Е. Н. [24], Палій С. В. [25], Патаракін Є. Д. [26], Тверезовська Н. Т. [34], Фещенко А. В. [36, с. 127-129], Яцишин А. В. [39]. Дослідники, залучаючи досвід закордонних викладачів [35; 40], виділили понад два десятки психологічних, соціальних і педагогічних аргументів на користь їх застосування. Зазначимо лише деякі, що, на нашу думку, є найбільш переконливими.

1. Соціальні мережі надають безкоштовне користування сервером для зберігання цифрових даних.

2. ЕСМ популярні серед молоді. Для учня це комфортне, зручне, позитивно налаштоване, звичне середовище. Якщо сайти дистанційного навчання відвідують тільки у разі потреби, то ЕСМ переглядають декілька разів на день. Нижче представлено фрагменти аналітичного звіту щодо особливостей аудиторії найпопулярніших ЕCM (Facebook, Twitter, Vkontakte). 


\section{Who visits facebook.com?}

Audience Demographics

How similar is this site's audience to the general internet population?

Gender

\section{Male}

Female
Education

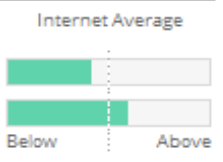

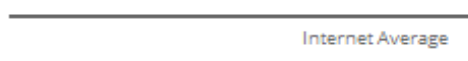

No College Some College

Graduate School
Browsing Location

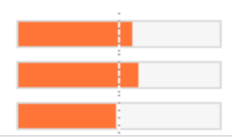

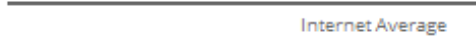

Home

School Work

Who visits twitter.com?

Audience Demographics

How similar is this site's audience to the general internet population?

Gender

\begin{tabular}{l|l|l}
\hline & & \\
& & \\
Male & & $\vdots$ \\
Female & & \\
& Below & Above
\end{tabular}

Education

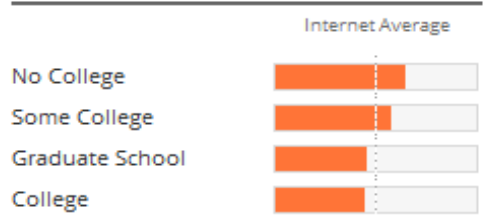

Browsing Location

\begin{tabular}{llll}
\hline & & \\
\hline Home & & \\
School & & \\
Work & & \\
& & \\
& Below & Above
\end{tabular}

Who visits vkontakte.ru?

Audience Demographics

How similar is this site's audience to the general internet population?

Gender

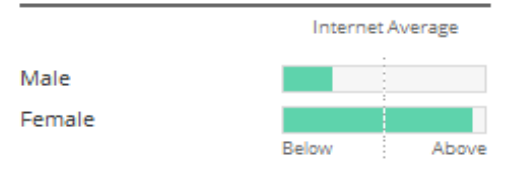

Education

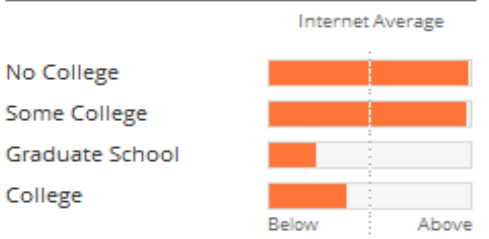

Browsing Location

Home

School

Work 
4. Дискусія, що розпочата на очному занятті, може бути продовжена у соціальній мережі. Це дозволяє учням/студентам проводити більше часу в активному навчанні через обговорення, у вчителя 3'являється можливість проводити аудиторні лекційні заняття в інтерактивному режимі, навчання набуває ознак безперервності.

5. Віртуальна навчальна група, створена в ЕСМ, завжди доступна за умови використання мобільного Інтернету.

6. У вчителів 3'являється можливість дізнатися більше про особистість учня, його інтереси.

Ці висновки знайшли підтвердження у результатах дисертаційних досліджень вітчизняних і закордонних педагогів-дослідників.

Вилегжаніною I. В. у дослідженні мережної форми навчання як засобу соціального розвитку підлітків розроблена технологія навчання, що включає ітераційні стадії «задум - інформаційні освітні ресурси - освітня спільнота - навчальна діяльність як діалог - образ мережі». У другій - четвертій стадіях активно використовувалися інструменти і ресурси ЕСМ. Наприклад, на стадії «навчальна діяльність як діалог» спочатку учні визначали теми, проблеми, напрямки, способи діяльності, форми представлення результатів, визначали соціальні ролі, потім індивідуально або спільно реалізовували заплановане, заповнювали спільні сторінки зі звітами, надавали відкритий доступ до портфоліо, висвітлювали поточні досягнення, оформляли відповіді на рефлексивні питання про діяльність у проекті. Учитель організовував мережну взаємодію учасників з метою взаємозбагачення, обговорення і доповнення робіт один одного [8, с. 17-18].

Дослідження Тверезовською Н. Т., різних підходів до використання ЕСМ у процесі навчання інформатичним дисциплінам майбутніх учителів дозволило зробити висновок про можливість значно підвищити інтерес студентів до самостійної позааудиторної роботи шляхом «інтеграції навчально-методичних матеріалів у соціальні мережі» [34, с. 3]

Кучаковська Г.А., досліджуючи роль соціальних мереж в активізації процесу навчання інформатичним дисциплінам майбутніх учителів початкової школи, отримала позитивні результати у використанні ЕСМ 3 метою забезпечення розвитку персоніфікованого навчального середовища студента, створення його портфоліо i навчального контенту дисциплін, адаптованого індивідуально для кожного студента. Умова успішності - спільне створення навчального контенту дисциплінистудентом разом з викладачем [15].

Бен Роман Сами дослідив лінгводидактичний потенціал ЕСМ [5] і розробив науково обгрунтоване дидактичне забезпечення навчання російській мові за допомогою соціальних мереж в Інтернеті (Facebooк, YouTube, ВКонтакте та ін.). Серед умов успішного використання соціальних мереж у навчальному процесі автор виділяє:

- визначеність правил роботи: дотримання правил мережного етикету; використання мовних норм; недопущення плагіату; дотримання кодексу академічної поведінки; установка на відповідальне й уважне ведення записів на сторінці мережі у зв'язку з їх відкритістю;

- чітка організація й адміністрування навчального процесу (публікація навчального плану, розкладу, оголошень, навчальних завдань), постійний педагогічний вплив;

- наявність системи у різних формах навчання: колективна або в малих групах (2-3 людини), індивідуальна робота.

Архиповою Т. Л. сформульовано педагогічні умови ефективної організації навчального процесу у ВНЗ засобами соціальних мереж. Особливістю формування i 
розвитку сучасного інформаційно-освітнього середовища дослідниця називає можливість забезпечити творчу дослідницьку діяльність викладача і студентів у процесі навчання за допомогою ЕСМ [3].

Зроблений нами огляд теоретичних і прикладних досліджень, присвячених проблемам еволюції й аналізу соціальних мереж, перспективний аналіз використання ЕСМ для організації і методичної підтримки навчально-виховного процесу й побудови власного навчального простору учня дозволили зробити висновки, що носять імовірнісний характер.

Створюючи «навчальні ситуації» [27, с. 32-34, 53], орієнтовні на використання ECM, учитель може сприяти формуванню універсальних навчальних дій (особистісних, регулятивних, пізнавальних, комунікативних), які забезпечать розвиток здібностей самостійного засвоєння нових знань й умінь, формування і розвиток критичного мислення, розвиток комунікативних умінь школярів. На рис. 2 схематично представлено процес проектування вчителем навчальної ситуації в умовах використання ЕСМ.

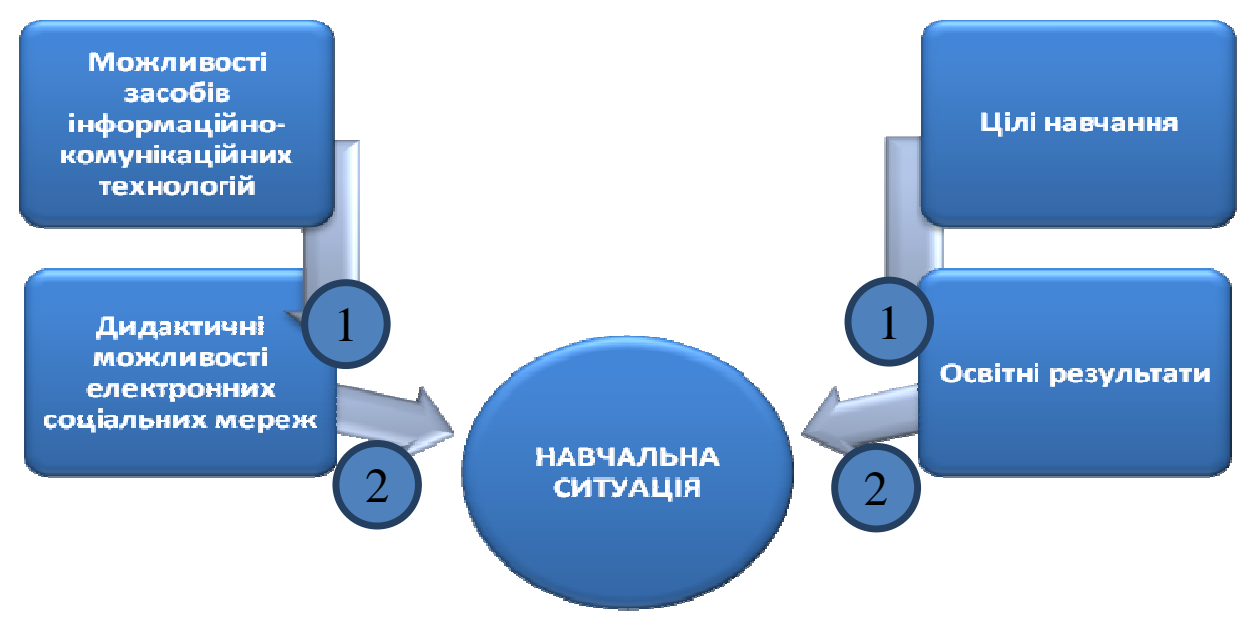

Рис. 2. Проектування навчальної ситуачїі (1 - конкретизаџія; 2 - формування)

\section{5. ВИСНОВКИ ТА ПЕРСПЕКТИВИ ПОДАЛЬШИХ ДОСЛІДЖЕНЬ}

Позитивно оцінюючи результати згадуваних досліджень, зазначимо, що використання електронних соціальних мереж з метою навчання ще не набуло в Україні достатнього для широкого впровадження науково-методичного психологопедагогічного обгрунтування. Молодь найчастіше використовує ЕСМ для нетематичного спілкування, прослуховування музики і перегляду фільмів, рідше - для самореалізації, участі у соціальних проектах і пошуку роботи. Разом з цим, старшокласники $\mathrm{i}$ студенти дотримуються думки про те, що ЕСМ можна використовувати для оперативного доступу до навчально-методичних матеріалів, зв'язку з викладачем і колективного виконання домашнього завдання, самостійного формування навчального контенту.

На основі співставлення можливостей засобів IКТ, їх конкретизації на рівні ЕСМ, i освітніх результатів, як орієнтирів навчання (табл. 1), можна сформулювати педагогічно доцільні практичні навчальні завдання і визначити організаційні форми навчання, у яких використання ЕСМ є найбільш ефективним. Перспективними, на нашу думку, є дослідження, що зорієнтовані на пошук нових методів навчання засобами ЕСМ; способів організації навчання в інформаційно-освітньому середовищі 
старшокласників на основі технологій електронних соціальних мереж; на відшукання шляхів подолання труднощів (нерозробленість системи завдань і вправ 3 використанням ЕСМ, недостатній рівень володіння засобами мережної комунікації, несформоване в учнів уміння критично оцінювати знайдену в Інтернет інформацію), 3 якими стикаються учителі, які використовують соціальні сервіси в навчальному процесі. 
Таблиия 1

\begin{tabular}{|c|c|c|c|c|c|c|c|c|c|}
\hline $\begin{array}{l}\text { Можливості } \\
\text { засобів ІКТ }\end{array}$ & \multicolumn{2}{|c|}{$\begin{array}{c}\text { Дидактичні можливості } \\
\text { соціальних мережних сервісів }\end{array}$} & \multicolumn{3}{|c|}{ Освітні результати } & \multicolumn{4}{|c|}{ Нові освітні результати } \\
\hline $\begin{array}{l}\text { Інформаційно- } \\
\text { довідкові }\end{array}$ & \multirow{2}{*}{$\begin{array}{l}\text { Доступ до великого } \\
\text { обсягу інформації } \\
\text { та } \\
\text { систематизованому } \\
\text { досвіду інших } \\
\text { людей (спільний } \\
\text { пошукінформації, } \\
\text { спільне зберігання } \\
\text { закладок) }\end{array}$} & \multirow{3}{*}{$\begin{array}{l}\text { Формування } \\
\text { досвіду спільної } \\
\text { діяльності } \\
\text { (спільне } \\
\text { створення, } \\
\text { редагування і } \\
\text { використанняв } \\
\text { мережі текстових } \\
\text { документів, } \\
\text { електронних } \\
\text { таблиць, } \\
\text { презентацій, } \\
\text { графічних } \\
\text { зображень, фото і } \\
\text { відеосервісів;ство } \\
\text { рення } \\
\text { гіпертекстових } \\
\text { об'єктів за } \\
\text { допомогою } \\
\text { засобів шіkі- } \\
\text { технологій) }\end{array}$} & $\begin{array}{l}\text { Розвиток } \\
\text { пізнавальної } \\
\text { активності учнів }\end{array}$ & & & $\begin{array}{l}\text { Використовувати } \\
\text { критерії і } \\
\text { показники } \\
\text { достовірності } \\
\text { інформації; }\end{array}$ & & & \multirow{5}{*}{$\begin{array}{l}\text { Готовність і } \\
\text { здатність учнів } \\
\text { до } \\
\text { саморозвитку } \\
\text { та самоосвіти } \\
\text { на основі } \\
\text { мотивації до } \\
\text { навчання і } \\
\text { пізнання }\end{array}$} \\
\hline $\begin{array}{l}\text { Інформаційно- } \\
\text { пошукові }\end{array}$ & & & $\begin{array}{l}\text { Формування у } \\
\text { них аналітичних } \\
\text { здібностей }\end{array}$ & & $\begin{array}{l}\text { Формування } \\
\text { дослідницьких } \\
\text { навичок }\end{array}$ & $\begin{array}{l}\text { аналізувати, } \\
\text { зіставляти } \\
\text { інформацію, що } \\
\text { отримана з різних } \\
\text { джерел }\end{array}$ & & \multirow{3}{*}{$\begin{array}{l}\text { Розвиток } \\
\text { навичок } \\
\text { проектної та } \\
\text { дослідницької } \\
\text { діяльності }\end{array}$} & \\
\hline $\begin{array}{l}\text { Теле- } \\
\text { комунікаційні }\end{array}$ & $\begin{array}{l}\text { Організація } \\
\text { активного } \\
\text { комунікаційного } \\
\text { процесу(форум,теле } \\
\text { конференція, } \\
\text { створення та } \\
\text { підтримка блогу) }\end{array}$ & & $\begin{array}{l}\text { Формування } \\
\text { комунікаційних } \\
\text { навичок }\end{array}$ & $\begin{array}{l}\text { Формування } \\
\text { організаційно- } \\
\text { практичних } \\
\text { здібностей }\end{array}$ & & $\begin{array}{l}\text { Оволодіння } \\
\text { навиками } \\
\text { використання } \\
\text { основних засобів } \\
\text { телекомунікацій; } \\
\text { формування } \\
\text { комунікативної } \\
\text { компетентності в } \\
\text { спілкуванні та } \\
\text { співпраці з } \\
\text { однолітками та } \\
\text { дорослими в } \\
\text { процесі освітньої, } \\
\text { суспільно корисної } \\
\text {, навчально- } \\
\text { дослідної, творчої } \\
\text { та інших видів } \\
\text { діяльності }\end{array}$ & $\begin{array}{l}\text { Уміння } \\
\text { здійснювати } \\
\text { спільну } \\
\text { інформаційну } \\
\text { діяльність, } \\
\text { працювати } \\
\text { індивідуально і в } \\
\text { групі }\end{array}$ & & \\
\hline Моделювальні & $\begin{array}{l}\text { Конструювання } \\
\text { нових знань }\end{array}$ & & & & $\begin{array}{l}\text { Формування } \\
\text { дослідницьких } \\
\text { навичок }\end{array}$ & & $\begin{array}{l}\text { Вміння } \\
\text { користуватися } \\
\text { сервісами для } \\
\text { планування } \\
\text { власної } \\
\text { діяльності }\end{array}$ & & \\
\hline Контролюючі & & & $\begin{array}{l}\text { Формування } \\
\text { уміння } \\
\text { самоперевірки }\end{array}$ & & & $\begin{array}{l}\text { Формування } \\
\text { відповідального } \\
\text { ставлення до } \\
\text { навчання }\end{array}$ & & & \\
\hline
\end{tabular}




\section{СПИСОК ВИКОРИСТАНИХ ДЖЕРЕЛ}

1. Акимов С. О. Моделирование влияния внутрифирменных коммуникаций в корпоративной социальнойсети на развитие компетенций сотрудников предприятия : автореферат дис. ... кандидата экономических наук : 08.00.13 / Акимов Сергей Олегович. - М., 2012. - 24 с.

2. Аксиологический и идеологический статус селевого общества в информационном социальном пространстве постановка проблеми [Електронний ресурс]. - Режим доступа: http://huminf.tsu.ru/ejurnal/magazine/3/luk_nur.htm. - Назва з екрану. - (дата звернення : 11.02.2015).

3. АрхиповаТ. Л. Социальные сети как средство организации учебного процесса / Архипова Т. Л., Осипова Н. В., Львов М. С. // Інформаційні технології в освіті: зб. наук. пр. - Випуск 22. - Херсон: ХДУ, 2015. - С. 7-18. - (http://www.ite.kspu.edu/webfm_send/819/1).

4. Barnes J. A. Class committees in a Norwegian island parish [Електронний pecypc] // Eugene Garfields, Ph.D. - URL: http://garfield. library.upenn. edu/classics1987/A1987H444400001.pdf.

5. Бен РомданСами. Методика использования социальных сетей в обучении русскому языку как иностранному тунисских студентов-филологов : уровень В1 : автореферат дис. ... кандидата педагогических наук : 13.00.02 / Бен РомданСами. - М., 2014. - 22 с.

6. Burt, Ronald S. «StructuralHoles: The Social Structure of Competition». - Cambridge : Harvard University Press. - (1992).

7. Воронкин А. С. Социальные сети: эволюция, структура, анализ / А. С. Воронкин // Электронный журнал «Образовательныетехнологии и общество» [Электронный ресурс]. - Казань, Исследовательская группа ITTAL, 2014. - №1(17)- C.650-675. - Режим доступа:http://cyberleninka.ru/article/n/sotsialnye-seti-evolyutsiya-struktura-analiz.

8. Вылегжанина И. В. Сетевая форма обучения как средство соціального развития подростков : автореферат дис. ... кандидата педагогических наук : 13.00.01 / Вылегжанина ИннаВитальевна. Киров, 2011. - 22 с.

9. Галіч Т. О. Соціальні Інтернет-мережі та віртуалізація суспільного життя [Текст] / Т. О. Галіч // Соціологія майбутнього: науковий журнал з проблем соціології молоді та студентства. - Х., 2010. - Вип. 1. - С. 145-152.

10. Гуревич Р. Інтернет і його соціальні мережі в сфері освіти: напрями використання / Р. Гуревич / Зб. наук. пр. III Міжнар. наук.-практ. конф. «Інформаційно-комунікаційні технології в сучасній освіті: досвід, проблеми, перспективи». - С. 52-56. - Режим доступу : http://ubgd.lviv.ua/konferenc/kon_ikt/plen_zasid/Gurevuch.pdf.

11. Дюлічева Ю. Ю. Перспективи використання соціальних мереж у навчальному процесі / Дюлічева Ю. Ю. // Збірник статей Міжнародної науково-практичної конференції «Інноваційні наукові технології: передовий світовий досвід»: Науково-дослідний центр інноваційних технологій, м. Кіровоград, 2012. - С. 59-64.

12. Івашньова С. В. Використання соціальних сервісів та соціальних мереж в освіті / С. В. Івашньова // Наукові записки НДУ ім. М. Гоголя. Психолого-педагогічні науки. - 2012. - № 2. - С. 15-17.

13. Крибель С. С. Использование социальных сетей в образовании / С. С. Крибель, В. В. Шобухова // Информатика и образование. - 2012. - № 4 (233). - С. 66-68.

14. Курбан O. В. Класифікація соціальних мережевих технологій як PR-інструментів [Електронний ресурс] / О. В. Курбан // Інформаційне суспільство. - 2013. - Вип. 17. - С. 41-43. - Режим доступу : http://nbuv.gov.ua/j-pdf/is_2013_17_11.pdf.

15. Кучаковська Г. А. Роль соціальних мереж в активізації процесу навчання інформатичним дисциплінам майбутніх вчителів початкової школи [Електронне видання] / Кучаковська Галина Андріївна // Інформаційні технології і засоби навчання. - 2015. - №3 (47). - С. 136-149. - Режим доступу : http://journal.iitta.gov.ua/index.php/itlt/article/view/1213\#.VaS1GV_tlBc.

16. Лещенко А. М. Социальные сети как механізм конструирования коммуникации в современном обществе : автореф. дис. ... к. философ. н. : 09.00.11 / Лещенко Александр Михайлович. Пятигорск, 2011. - 25 с.

17. Малышева Н. А. Роль социальных сетей в модели дистанционного обучения студентов художественных специальностей [Електронний ресурс] / Малышева Н. А. // Политематический сетевой электронный журнал Кубанского государственного аграрного университета. - 2013. - № 86 (02). - Режим доступу: http://ej.kubagro.ru/2013/02/pdf/02.pdf (дата звернення: 10.08.15).

18. Mark Granovetter. Professor in the School of Humanities and Sciences [Електронний ресурс]. http://www.stanford.edu/dept/soc/people/mgranovetter/index.html.

19. Mary Meeker.TakesYouon a Tourofthe 2015 Internet TrendsReport.27 мая 2015 года [Електронний pecypc]. - Режим доступу : http://recode.net/. - (дата звернення : 29.07.2015). 
20. Матрехина Н. В. Социальная сеть человека в контексте его жизненных ситуаций : автореферат дис. ... кандидата психологических наук : 19.00.05 / Матрехина Н. В./ Рос. гос. пед. ун-т им. А. И. Герцена. - Санкт-Петербург, 2006. - 22 с.

21. Мнацаканян О. Л. Методика использования социальных сетевых сервисов в школьном курсе информатики : автореферат дис. ... кандидата педагогических наук : 13.00.02 / Мнацаканян Ольга Леонидовна. - М., 2012. - 23 с.

22. Морено Я. Л. Социометрия: экспериментальный метод и наука об обществе / Я. Л. Морено. - М. : Академ. проект, 2004. - 320 с.

23. Онищенко О. С. Соціальні мережі як чинник розвитку громадянського суспільства : монографія / О. С. Онищенко, В. М. Горовий, В. І. Попик та ін.; НАН України, Нац. б-ка України ім. В. І. Вернадського. - К., 2013. - 220 с.

24. Павличенко Е. Н. Социальные сети как інструмент модернизации образования/ Е.Н. Павличенко //Народное образование. - 2012. - № 1. - С. 42-47.

25. Палій С. В. Соціальні мережі як засіб комунікації електронного навчання [Електронний ресурс] / Палій С. В. // Управління розвитком складних систем. - 2013. - № 13. - С. 152-156. - Режим доступу : http://urss.knuba.edu.ua/files/zbirnyk-13/152-156.pdf. - (дата звернення : 11.08.15).

26. Патаракин Е. Д. Социальные взаимодействия и сетевое обучение 2.0[Текст]: монографія/ Е. Д. Патаракин. - М. : НП«Современные технологии в образовании и культуре», 2009.- 176 с.

27. Пінчук О. П. Формування предметних компетентностей учнів основної школи в процесі навчання фізики засобами мультимедійних технологій : дис. ... канд. пед. наук : 13.00.02 / Пінчук Ольга Павлівна. - Київ, 2010. - 255 с.

28. Про Національну стратегію розвитку освіти в Україні на період до 2021 року [Електронний pecypc]. - Режим доступу: http://zakon4.rada.gov.ua/laws/show/344/2013.

29. Reimagining teaching in a blended classroom [Електронний ресурс] // TNTP reimagine teaching. Working Paper. - $\quad$ Nov 2014. - $17 \quad$ p. $\quad$ - $\quad$ Режим доступу : http://tntp.org/assets/documents/TNTP_Blended_Learning_WorkingPaper_2014.pdf.

30. Social Network Sites: Definition, Histori and Scholarship[Електронний ресурс]. - Access mode: http: // jcmc . Indiana.edu/voll 3/issue 1/boyd.Ellison.html. - (дата звернення : 15.01.2015).

31. Социальные сети как актуальный способ самовыражения массового человека[Електронний pecypc]. - Режим доступу: http://www.moluch.ru/archive/39/4592/. - (дата звернення : 02.03.2015).

32. Співаковський О. В., Філософія трисуб'єктної дидактики в системі підготовки майбутнього вчителя початкових класів / О. В. Співаковський, Л. С. Петухова, В. В. Коткова // Комп’ютер у школі та сім’ї. - 2014. - № 3. - С. 7-11.

33. Стратегія розвитку інформаційного суспільства в Україні. [Електронний ресурс]. - Режим доступу: http://zakon2.rada.gov.ua/laws/show/386-2013-p\#n8.

34. Тверезовська Н. Т. Роль і місце соціальних мереж у формуванні освітньо-інформаційного середовища аграрних університетів / Н. Т. Тверезовська, С. М. Мигович // Науковий вісник Національного університету біоресурсів і природокористування України. Серія : Педагогіка, психологія, філософія - - 2012. - Вип. 175(3). - С. 291-298. - Режим доступу : http://www.mnau.edu.ua/files/02_02_01_10/mygovich/2012-mygovich-rmsm.pdf.

35. The Facebook Classroom: 25 Facebook Apps That Are Perfect for Online Education. [Електронний pecypc]. - Режим доступу: http://www.collegedegree.com/library/college-life/15-facebook-apps-perfectfor-online-education - (дата звернення: 11.08.2015).

36. Фещенко А. В. Социальные сети в образовании: аналіз опыта и перспективы развития/ Фещенко А. В. //Открытое дистанционное образование. - №3 (43).- Томск: ТГУ АСОУ, 2011. - С. 44-49.

37. Freeman, Linton C. Research Professor. - Режим доступу: http://moreno.ss.uci.edu/.

38. Яценко А. Л.Функциональные особенности социальных сетей в коммуникационном пространстве глобализирующегося общества : автореферат дис. ... кандидата философских наук : $09.00 .11 /$ Яценко Андрей Леонидович. - Ставрополь, 2012. - 21 с.

39. Яцишин А. В. Застосування віртуальних соціальних мереж для потреб загальної середньої освіти / А.В.Яцишин // Інформаційні технології в освіті. - 2014. - № 19. - С. 119--126.

40.50 Reasons to Invite Facebook Into Your Classroom. [Електронний ресурс]. - Режим доступу : http://www.onlinecollege.org/2011/07/18/50-reasons-to-invite-facebook-into-your-classroom - (дата звернення : 11.08.15). 


\title{
ИСТОРИКО-АНАЛИТИЧЕСКИЙ ОБЗОР РАЗВИТИЯ СОЦИАЛЬНЫХ СЕТЕВЫХ ТЕХНОЛОГИЙ И ПЕРСПЕКТИВЫ ИХ ИСПОЛЬЗОВАНИЯ В ОБУЧЕНИИ
}

\author{
Пинчук Ольга Павловна \\ кандидат педагогических наук, старший научный сотрудник, заведующая отделом технологий открытой \\ учебной среды \\ Институт информационных технологий и средств обучения НАПН Украины, г. Киев, Украина \\ opinchuk100@gmail.com
}

\begin{abstract}
Аннотация. В статье представлено краткое историческое описание возникновения и исследования социальных сетей, результаты современных исследований в философских и психологических науках, социальных коммуникациях и экономике. Проанализировано современное состояние педагогических исследований электронных социальных сетей и формирования практического опыта их использования. Результаты исследований социальных сетей изучены и описаны с точки зрения их формирования в условиях расширения коммуникационного пространства глобализированного социума и трансформации старых, а также появления новых практик взаимодействия социальных субъектов в различных сферах жизнедеятельности общества, в образовании в частности. В использовании электронных социальных сетей автор видит потенциал решения проблем синхронизации различных образовательных форматов для построения целостной траектории индивидуального обучения.
\end{abstract}

Ключевые слова: электронные социальные сети; информационно-образовательная среда; информационно-коммуникационные технологии; обучение.

\section{HISTORICAL AND ANALYTICAL REVIEW OF SOCIAL NETWORKING TECHNOLOGIES AND PROSPECTS OF THEIR USE IN TRAINING}

\author{
Olga P. Pinchuk \\ $\mathrm{PhD}$ (in Pedagogics), senior researcher, head of the Department of Technology of Open Learning Environment \\ Institute of Information Technologies and Learning Tools of National Academy of Educational Sciences of \\ Ukraine, Kyiv, Ukraine \\ email@email.com
}

\begin{abstract}
The article presents a brief historical description of the origin and the study of social networks, the results of current research in the philosophical and psychological sciences, social communication and economics. The current state of educational research of electronic social networking and forming of practical experience of their use are analyzed. The results of studies of social networks are analyzed in terms of their formation in relation with increasing globalized communication space and the transformation of the old society and the emergence of new practices of interaction between social subjects in various fields of society, including education. In the use of electronic social networking author sees potential for solving problems of synchronizing of different educational formats for building a coherent individual educational trajectory.
\end{abstract}

Key words: electronic social networks; information and educational environment; information and communication technologies; education.

\section{REFERENCES (TRANSLATED AND TRANSLITERATED)}

1. Akimov S. O. Modeling the impact of intra-corporate communications in the social network on the development of competence of employees of the enterprise: the author's abstract dis. ... the candidate of economic sciences : 08.00.13 / Akimov Sergej Olegovich. - M., 2012. - 24 p. (in Russian).

2. Axiological and ideological status of the network society in the Information Statement of the problem social space[online]. - Available from: http://huminf.tsu.ru/e-jurnal/magazine/3/luk_nur.htm. - (date accessed : 11.02.2015)(in Russian).

3. Arhipova T. L.Social networking as a means of organizing the educational process / Arhipova T. L., 
Osipova N. V., L'vov M. S. // Information Technology in Education: Coll. Science. pr. - Issue 22. Kherson: KSU, 2015. - P. 7-18. - (http://www.ite.kspu.edu/webfm_send/819/1) (in Russian).

4. Barnes J. A. Class committees in a Norwegian island parish [online] // Eugene Garfields, Ph.D. - URL: http://garfield. library.upenn. edu/classics1987/A1987H444400001.pdf (in English).

5. Ben Romdan Sami. Methods Using a social network for Russian language learning as a foreign language for Tunis students: Level B1: Abstract Dis. ... Candidate pedagogical sciences : 13.00 .02 / Ben Romdan Sami. - M., 2014. - 22 p. (in Russian).

6. Burt, Ronald S. «Structural Holes: The Social Structure of Competition». - Cambridge: Harvard University Press. - (1992) (in English).

7. Voronkin A. S.Social Networks: evolution, structure, analysis [online] / A. S. Voronkin // Electronic journal "Educational Technology \& Society". - Kazan, the Study Group ITTAL, 2014. - №1(17), P.650-675. - Available from:http://cyberleninka.ru/article/n/sotsialnye-seti-evolyutsiya-struktura-analiz (in Russian).

8. Vylegzhanina I. V.The network form of training as a means of social development of adolescents: abstract dis. ... the candidate of pedagogical sciences : 13.00.01 / Vylegzhanina Inna Vital'evna. - Kirov, 2011. - 22 p. (in Russian).

9. Halich T. O. Social Internet network and virtualization social life [Text] / T. O. Halich // Sociology future: Journal of the problems of sociology of youth and students. - Kh., 2010. - Issue. 1. - P. 145-152 (in Ukrainian).

10. Hurevych R.Internet and its social networks in education: Trends use / R. Hurevych / Coll. Science. pr. Third International. scientific-practic. conf. "ICT in modern education: experience, problems and prospects". - $\quad$ P. 52-56. - $\quad$ Available from: http://ubgd.lviv.ua/konferenc/kon_ikt/plen_zasid/Gurevuch.pdf (in Ukrainian).

11. Diulicheva Yu. Yu. Prospects for the use of social networking in education / Diulicheva Yu. Yu.// Collection of articles of the International Scientific Conference "Innovative scientific technology, advanced world experience": Research Center for Innovative Technologies, Kirovograd, 2012. - P. 59-64 (in Ukrainian).

12. Ivashnova S. V. The use of social services and social networking in education / S. V. Ivashnova // Scientific notes NSU them. Gogol. Psycho-pedagogical science.- 2012. - № 2. - P. 15-17.

13. Kribel' S. S. Using social network in education / S. S. Kribel', V. V. Shobuhova// Information and education. - 2012. - № 4 (233). - P. 66-68 (in Russian).

14. Kurban O. V.Classification of social networking tools as PR[online] / O. V. Kurban // Information society. - 2013. - Vol. 17. - P. 41--43. - Available from: http://nbuv.gov.ua/j-pdf/is_2013_17_11.pdf (in Ukrainian).

15. Kuchakovska H. A. The role of social networks in enhancing the learning process informatic disciplines of future elementary school teachers [online] / Kuchakovska Halyna Andriivna // Information technology and learning tools. - 2015. - №3 (47). - P. 136-149. - Available from:http://journal.iitta.gov.ua/index.php/itlt/article/view/1213\#.VaS1GV_tlBc (in Ukrainian).

16. Leshhenko A. M. Social networks as a mechanism for communication design in contemporary society: Author. Dis. ... the candidate of philosophical sciences : 09.00.11 / Leshhenko Aleksandr Mihajlovich. Pyatigorsk, 2011. - 25 p. (in Russian)

17. Malysheva N. A. The role of social netw.orks in the model of distance learning students of art specialties [online] / Malysheva N. A. // Multidisciplinary network electronic magazine Kuban State Agrarian University. - 2013. - № 86 (02). - Available from: http://ej.kubagro.ru/2013/02/pdf/02.pdf (date accessed: 10.08.15) (in Russian).

18. Mark Granovetter. Professor in the School of Humanities and Sciences [online]. - Available from: http://www.stanford.edu/dept/soc/people/mgranovetter/index.html (in English).

19. Mary Meeker. Takes You on a Tour of the 2015 Internet Trends Report. May 27, 2015 [online]. Available from: http://recode.net/. - (date accessed : 29.07.2015) (in English).

20. Matrehina N. V. Social network rights in the context of his life experiences: abstract dis. ... the candidate of psychological sciences : 19.00.05 / Matrehina N. V. / Russian State Pedagogical University named after Herzen. - Saint Petersburg, 2006. - 22 p. (in Russian).

21. Mnacakanjan O. L. The technique of using social networking services in the school course of computer science: the author's abstract dis. ... the candidate of pedagogical sciences : 13.00 .02 / MnacakanjanOl'gaLeonidovna. - M., 2012. - 23 p. (in Russian).

22. MorenoJa. L. Sociometry: experimental method, and a science of society / Ja. L. Moreno (Jacob L. Moreno). - M. :Academic Project, 2004. - 320 p. (in Russian).

23. Onyshchenko O.S. Social media as a factor in the development of civil society: Monograph / O. S. Onyshchenko, V. M. Horovyi, V. I. Popykand other; NAS of Ukraine Vernadsky National Library of Ukraine. - K., 2013. - 220 p. (in Ukrainian). 
24. Pavlichenko E. N. Social networking as a tool for the modernization of education / E. N. Pavlichenko//Narodnoeobrazovanie. - 2012. - № 1. - P. $42-47$ (in Russian).

25. Palii S. V.Social networks as a means of communication eLearning [online] / Palii S. V. // Development Management of Complex Systems. - 2013. - № 13. - P. 152-156. - Available from:http://urss.knuba.edu.ua/files/zbirnyk-13/152-156.pdf. - (dateaccessed: 11.0815). (in Ukrainian).

26. Patarakin E. D.Social interaction and online learning 2.0[Text]: monografiya / E.D. Patarakin. - M.:NC «Modern technologies in education and culture», 2009. - 176 p. (in Russian).

27. Pinchuk O. P. Formation of subject competency of basic school students in the process of teaching physics by means of multimedia technologies : the author's abstract dis. ... the candidate of pedagogical sciences: 13.00.02 / Pinchuk Olga Pavlivna. - Kyiv, 2010. - 255 p. (in Ukrainian).

28. On the National Strategy for the Development of Education in Ukraine until 2021 [online]. - Available from:http://zakon4.rada.gov.ua/laws/show/344/2013 (in Ukrainian).

29. Reimagining teaching in a blended classroom [online] // TNTP reimagine teaching. Working Paper. $\begin{array}{lllcccc}\text { Nov 2014. } & - & 17 & \text { p. } & - & \text { Available } & \text { from } \\ \text { http://tntp.org/assets/documents/TNTP } & \text { Blended Learning } & \text { WorkingPaper 2014.pdf (in English). }\end{array}$

30. Social Network Sites: Definition, History and Scholarship [online]. - Available from: http: // jcmc . Indiana.edu/voll 3/issue 1/boyd.Ellison.html. - (date accessed : 15.01.2015) (in English).

31. Social networks as a way to express the actual mass man [online]. - Available from:http://www.moluch.ru/archive/39/4592/. - (dateaccessed : 02.03.2015) (inRussian).

32. Spivakovskyi O. V., Philosophy trysub'yektnoyi didactics in training future teachers of primary school / O. V. Spivakovskyi, L. Ye. Petukhova, V. V. Kotkova // Computer in school and family. - 2014. - № 3. P. 7-11 (inUkrainian).

33. Strategy for Information Society Development in Ukraine. [online]. - Available from:http://zakon2.rada.gov.ua/laws/show/386-2013-p\#n8 (in Ukrainian).

34. Tverezovska N. T. Role of social media in shaping the educational information environment of agricultural universities / N. T. Tverezovska, S. M. Myhovych// Scientific Bulletin of National Agricultural University of Ukraine. Series: pedagogy, psychology, philosophy . - 2012. - Vol. 175 (3). P. 291-298. - Available from:http://www.mnau.edu.ua/files/02_02_01_10/mygovich/2012-mygovichrmsm.pdf (in Ukrainian).

35. The Facebook Classroom: 25 Facebook Apps That Are Perfect for Online Education. [online]. Available from: http://www.collegedegree.com/library/college-life/15-facebook-apps-perfect-for-onlineeducation - (date accessed : 11.08.2015) (in English).

36. Feshhenko A. V.Social networks in education: analysis of the experience and perspectives of development / Feshhenko A. V. // Open Distance Education. - №3 (43).- Tomsk: TSUASEU, 2011. - P. 44-49 (in Russian).

37. Freeman, Linton C. Research Professor [online]. - Available from:http://moreno.ss.uci.edu/.(in Russian)

38. JacenkoA. L. Functional features of social networks in the communication space of the globalized society :abstract dis. ... the candidate of philosophical sciences: 09.00.11 / Jacenko Andrej Leonidovich. Stavropol, 2012. - 21 p. (in Russian).

39. Yatsyshyn A. V. The use of virtual social networks for the purpose of secondary education / A. V. Yatsyshyn // Information Technologies in Education. - 2014. - № 19. - P. 119-126 (in English).

40.50 Reasonsto Invite Facebook Into Your Classroom. [online]. - Available from : http://www.onlinecollege.org/2011/07/18/50-reasons-to-invite-facebook-into-your-classroom - (date accessed : 11.08.15) (in English).

\section{(cc) EY-NC-SA}

This work is licensed under Creative Commons Attribution-NonCommercial-ShareAlike 4.0 International License. 